\title{
Designer natriuretic peptides for heart failure: advanced in clinical development
}

\author{
John Burnett Jr.
}

From 5th International Conference on cGMP: Generators, Effectors and Therapeutic Implications

Halle, Germany. 24-26 June 2011

\section{Background}

The increasing burden of heart failure (HF) is a major unmet need for new therapeutics. No new drug has been approved for HF for over a decade. The natriuretic peptides as endogenous activators of particulate guanylyl cyclase (GC) receptors represent an unparalleled opportunity for novel therapeutic agents for HF. Specifically, the GC-A receptor activated by ANP and BNP and GC$B$ activation by CNP mediate beneficial pleiotropic actions, which include natriuresis, vasodilatation, suppression of the renin-angiotensin-aldosterone system, inhibition of cardiomyocyte hypertrophy, retardation of fibrosis and improvement in ventricular function and structure.

\section{Results}

CD-NP (Cenderitide) represents the first in class designer natriuretic peptide which co-activates both GC-A and GC-B. Through rational drug design to coactivate GC-A and GC-B together with increased resistance to peptidase degradation, $\mathrm{CD}-\mathrm{NP}$ possesses actions which make CD-NP an innovative protein therapeutic to target the heart, kidney, vasculature and endocrine system in HF to reduce rehospitalization following acute decompensated HF.

\section{Conclusion}

Here we review the biology, preclinical development and recent human studies advancing CD-NP as a chronic peptide therapeutic designer peptide to reduce the risk of rehospitalization in human chronic HF.

Published: 1 August 2011

Correspondence: burnett.john@mayo.edu

Mayo Clinic, Mayo Heart and Lung Research Center, Rochester, USA
doi:10.1186/1471-2210-11-S1-01

Cite this article as: Burnett: Designer natriuretic peptides for heart failure: advanced in clinical development. BMC Pharmacology 201111 (Suppl 1):01.
Submit your next manuscript to BioMed Central and take full advantage of:

- Convenient online submission

- Thorough peer review

- No space constraints or color figure charges

- Immediate publication on acceptance

- Inclusion in PubMed, CAS, Scopus and Google Scholar

- Research which is freely available for redistribution

Submit your manuscript at www.biomedcentral.com/submit
() Biomed Central 